\title{
CIÊNCIANATURA
}

\section{Evaluation of the electrical conductivity of forest seeds after digestive tract of wild birds}

\author{
Avaliação da condutividade elétrica de sementes florestais pós trato digestório de aves \\ silvestres
} Sérgio Thode Filho ${ }^{1,5^{*}}$, Heider Alves Franco ${ }^{2}$, Emanuele Nunes de Lima Figueiredo Jorge
Miquéias da Silva Fernandes ${ }^{4}$, Ildemar Ferreira ${ }^{6}$ e Bruno Pereira Berto

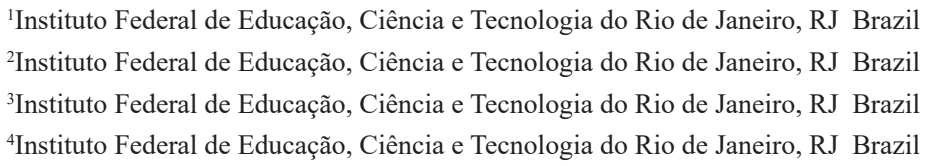

${ }^{5}$ Programa de Pós-graduação em Ciência, Tecnologia e Inovação em Agropecuária, Universidade Federal Rural do Rio de Janeiro, RJ, Brazil

${ }^{6}$ Departamento de Biologia Animal, Instituto de Ciências Biológicas e da Saúde, Universidade Federal Rural do Rio de Janeiro, RJ, Brazil

${ }^{7}$ Departamento de Biologia Animal, Instituto de Ciências Biológicas e da Saúde, Universidade Federal Rural do Rio de Janeiro, RJ, Brazil

\section{Abstract}

The production of seedlings encompasses the need for knowledge of plant physiology, mainly related to seeds and their minutiae. The seed is the vehicle that carries the full genetic potential of a cultivar with superior characteristics. Vigor can be described as that seed property that determines its emergence under unfavorable conditions. According to the International Seed Testing Association (ISTA). The process of reforestation can happen through the production of seedlings and, through seed dispersal, this can occur due to the action of the plant itself (autochory), water (hydrochory), wind (anemochory), animals (zoochory), etc. The current work aimed to investigate the feasibility of using the individual electrical conductivity test to evaluate the physiological quality of seeds of forest species after passage through the digestive tract of wild birds. The results allowed inferring that the forest seeds after digestive tract of wild birds presented low electrical conductivity at the individual level. Thus, the seeds in study no presented loss force after digestive tract of wild birds. Therefore, the birds only performed the role of individual dispersant.

\section{Keywords: Ornithochoric; Electrical Conductivity; Forest Seeds}

\section{Resumo}

A produção de mudas engloba a necessidade de conhecimento da fisiologia vegetal, principalmente relacionada às sementes e suas minúcias. A semente é o veículo que carrega todo o potencial genético de uma cultivar com caracteristicas superiores. O vigor pode ser descrito como aquela propriedade da semente que determina sua emergência sob condições desfavoráveis. De acordo com a Associação Internacional de Testes de Sementes (ISTA). O processo de reflorestamento pode acontecer através da produção de mudas e, através da dispersão de sementes, isso pode ocorrer devido à ação da própria planta (autocoria), água (hidrocoria), vento (anemocoria), animais (zoocoria), etc. O presente trabalho teve como objetivo investigar a viabilidade do uso do teste de condutividade elétrica individual para avaliar a qualidade fisiológica de sementes de espécies florestais após passagem pelo trato digestório de aves silvestres. Os resultados permitiram inferir que as sementes da floresta após o trato digestivo das aves silvestres apresentaram baixa condutividade elétrica no nível individual. Assim, as sementes em estudo não apresentaram perda de vigor após o trato digestório das aves silvestres. Portanto, as aves só desempenharam o papel de dispersor individual.

Palavras-chave: Ornitocoria; Condutividade Elétrica; Sementes Florestais

*sergio.thode@ifrj.edu.br 


\section{Introduction}

Forests play important roles in the ecosystem, among which we can highlight: $\mathrm{CO}_{2}$ consumption, ecosystem services, habitat for several species, soil protection, income source, food and forest products, as well as being the source of biodiversity more important. In Brazil, special emphasis is given to the Amazon Rainforest, which despite the constant advances in deforestation is still considered the largest rainforest in the world (FAO, 2011).

The reproductive process of the superior plants happens from the meeting between the male and female gametes when the fertilization of the egg of the flower that gives rise to fruit and seeds takes place. The seeds have their origin from the cross between the male and female gametes of the flower. For this it is necessary to the action of pollinating agents, which can be: the wind, the insects and the gravity. However, it is important that the reproductive apparatus be developed, that is, suitable for reproduction, so that when transported the pollen grain, it can be allocated in the female flower in order to fertilize the egg (BESPALHOK; GUERRA; OLIVEIRA, 2018).

The production of seedlings encompasses the need for knowledge of plant physiology, mainly related to seeds and their minutiae. The seed is the vehicle that carries the full genetic potential of a cultivar with superior characteristics. It has attributes of genetic, physical, physiological and sanitary quality that gives it the guarantee of a good agronomic performance (BRASIL, 2003; FRANCO, 2016).

Vigor can be described as that seed property that determines its emergence under unfavorable conditions. According to the International Seed Testing Association (ISTA), vigor is an index of the degree of physiological deterioration and / or mechanical integrity of a batch of high germination seeds, representing its broad ability to establish in the environment. According to the Association of Official Seed Analysts (AOSA) seed vigor is taken as seed property that determines the potential for rapid and uniform emergence and for the development of normal seedlings under a wide range of field conditions (AOSA, 1983; HAMPTON; TEKRONY, 1995).

The process of reforestation can happen through the production of seedlings and, through seed dispersal, this can occur due to the action of the plant itself (autochory), water (hydrochory), wind (anemochory), animals (zoochory), etc. However, special attention should be given to the action of the birds, given their ample capacity of migration between the different environments. However there are few studies that relate the effect of zoochory, mainly ornithochory on the physiological quality of seeds (REIS, 2003; DARIO, 2004).

The most used method to evaluate the physiological quality of seeds is carried out based on the traditional germination test (PASSOS et al., 2008). However, such testing for seed of forest species may take weeks or even months to complete the results. Thus, the development and improvement of the methodology for rapid feasibility evaluation tests promises to make the production process more efficient and to aid decision making on seed lots. However, electrical conductivity tests with seeds of forest species are still scarce, especially those developed with the individual method, which provide greater fidelity to the results so that through this one can define the test by the mass methods. Stallbaun et al. (2015), using the individual electrical conductivity test with seeds of Anadenanthera falcata concluded that the applied method was compatible with the standard germination test. The current work aimed to investigate the feasibility of using the individual electrical conductivity test to evaluate the physiological quality of seeds of forest species after passage through the digestive tract of wild birds 


\section{Materials and Methods}

An expedition was conducted in a fragmented area of Atlantic Forest in process of reforestation in the campus of the Instituto Federal de Educação, Ciência e Tecnologia do Rio de Janeiro (IFRJ) in the Municipality of Pinheiral, State of Rio de Janeiro (22³1'29.73”'S; 4359’37.08”W). One white-bearded manakin Manacus manacus (Linnaeus, 1766), one sayaca tanager Tangara sayaca Linnaeus, 1766, one rufous-bellied thrush Turdus rufiventris Vieillot, 1818 and one blue dacnis Dacnis cayana (Linnaeus, 1766) was captured with mist nets. The birds was kept in individual boxes with clean ground paper. After identification of the species, the bird was photographed and released. The seeds was taken from the fresh feces from each individual bird and identified according to the Manual of Identification and Cultivation of Native Arboreal Plants of Brazil (LORENZI, 2016). Seeds of the following species was shed by the birds: Ficus calyptroceras (Miq.) Miq., Ficus enormis (Miq.) Miq. and Ficus obtusiuscula (Miq.) Miq. (Rosales: Moraceae); and Annona emarginata (Schltdl.) H. Rainer, Annona neosalicifolia H. Rainer and Xylopia brasiliensis Spreng (Magnoliales: Annonaceae). After identification, asepsis was performed, leaving the seeds in sodium hypochlorite solution (2\%) for $5 \mathrm{~min}$ and then washing under running water. In laboratory, drying was carried out in a germinat chamber type BOD (CIENLAB and model CE-300/350-F) with a temperature of approximately $30{ }^{\circ} \mathrm{C}$ for 30 min. For conduct the electrical conductivity (EC) test, the recommendations proposed by Krzyzanowski et al. (1999), Flavio and Paula (2010) and Guollo et al. (2017) was followed with adaptations. The experimental design was completely randomized with six treatments with three replicates. The tests was performed by the individual method (by seed) for 36 hours. The seeds was placed in individual plastic containers containing $15 \mathrm{~mL}$ of distilled water and placed in a germinat chamber with constant temperature of $25^{\circ} \mathrm{C}$. Additionally, the EC was evaluated in five soak periods: 2, 4, 6, 24 and 36 hours. The parameters of the study was evaluated using a multiparameter probe AKSO Combo 5 and the results was expressed in $\mu \mathrm{S} \mathrm{cm}^{-1}$.

The data was submitted to analysis of variance (ANOVA) and the means was compared by the Tukey test $\mathrm{p} \leq 0.05$ of probability between the same ones (COSTA NETO, 1977; MILLER; MILLER, 1993).

\section{Results and Discussion}

The mean values of EC as a function of the different soak periods are shown in figure 1. Significant differences was observed in all the soak periods. It was found that the seed of $X$. brasiliensis presented the lowest EC value in all periods.

The species $F$. obtusiuscula was the one with the highest amount of leachate in $24 \mathrm{hs}\left(45 \mu \mathrm{S} \mathrm{cm}^{-1}\right)$, which was the most permeable until the end of the imbibition period $\left(88 \mu \mathrm{S} \mathrm{cm}^{-1}\right)$. None of the seeds under study had EC greater than $88 \mu \mathrm{S} \mathrm{cm}^{-1}$.

Increased EC can indicate inability to maintain membrane integrity, resulting in losses in germination (CHANG; SUNG, 1998). The seeds of $X$. brasiliensis was higher ability to maintain high germination potential due to the lower EC observed over the test period.

Different values for EC was possible to be found when adopting the individual methodology for the test (MARCOS FILHO, 2015). However, data on individual EC of the species under study showed similar growth behavior.

The highest amount of leachate in the exudate occurs due to the loss of cell membranes integrity (BOTOTTI et al., 2008). As the seed grows older, its deterioration occurs, consequently, the loss of the integrity of the cell membrane 
systems, causing an increase in its permeability, which results in leaching of electrolytes and higher electrical conductivity (SANTOS, PAULA, 2005; OLIVEIRA, 2012).

Figure 1 - Evaluation of the electrical conductivity in different times of seed soak: Ficus obtusiuscula (A); Ficus enormis (B); Ficus calyptroceras (C); Annona emarginata (D); Annona neosalicifolia (E); e Xylopia brasiliensis (F). Means followed by the same lowercase letter do not differ statistically from each other by Tukey test $\mathbf{p} \leq 0.05$ probability


In the case of seeds with lower values of EC (high vigor), the reorganization of the membranes occurs faster, causing the release of exudates to be practically zero and when a seed is not viable or with low vigor, a higher release of exudates causes the increase of EC (MARCOS FILHO, 2015).

Several factors besides the seed imbibition period may have an influence on the results of the EC test, which can be cited: water quality and temperature, test environment temperature, seed water content, number of seeds used for seed test, genotype, the equipment used to read the EC, the presence of mechanical damages and injuries in the seeds and the 
age of the seeds (DIAS; MARCOS FILHO 1996; VIEIRA; KRZYZANOWSKI, 1999; GASPAR; NAKAGAWA, 2002; MARCHI; CICERO, 2002).

Guollo et al. (2017) report that it is possible to infer that EC tests should be established specifically for each species, due to the differences found between them. There are variations in the absorption capacity for each type of seed, due to its shape, size and functionality of the pores, control of water exchange, waxy material that constitutes the epidermis of the integument and the degree of adhesion of the forehead to the cotyledon. These characteristics can be taken into account with regard to the time of imbibition of the seeds.

From the individual EC test, seed quality can be determined through viability and vigor, which represent different attributes of the seed (GUOLLO et al., 2017). According to Steere et al. (1981), the individual EC test was created to correct problems in performing the mass EC test with damaged or hard seeds, which present variations in the leaching capacity.

Thus, it is important to mention that the individual EC test is primordial with regard to establishing seed methodologies, due to the fact that through it is possible to prove the alterations of the reading in different conditions found in the seeds. However, there are few studies of individual EC related to forest seeds (GUOLLO et al., 2017). It is also understood that the fact that the seeds had been obtained from bird feces, the evaluation of the individual EC will contribute to the understanding of the physiological behavior of the forest seeds through ornithochoric dispersion.

\section{Conclusions}

The results allowed inferring that the forest seeds after digestive tract of wild birds presented low electrical conductivity at the individual level. It was found that the seed of $X$. brasiliensis presented the lowest EC value in all periods. The species F. obtusiuscula was the one with the highest amount of leachate in $24 \mathrm{hs}\left(45 \mu \mathrm{S} \mathrm{cm}^{-1}\right)$, which was the most permeable until the end of the imbibition period $\left(88 \mu \mathrm{S} \mathrm{cm}^{-1}\right)$. Thus, the seeds in study no presented loss force after digestive tract of wild birds. Therefore, the birds only performed the role of individual dispersant.

\section{Acknowledgments}

This study was supported by Coordenação de Aperfeiçoamento de Pessoal de Nível Superior (CAPES), Conselho Nacional de Desenvolvimento Científico e Tecnológico (CNPq), Fundação Carlos Chagas Filho de Amparo à Pesquisa do Estado do Rio de Janeiro (FAPERJ). Field-collecting permits were issued to B.P. Berto by SISBIO/ICMBio (license 49605) and CEUA/UFRRJ (protocol IV-036/2014). We are thankful to staff and managers at the Instituto Federal de Educação, Ciência e Tecnologia do Rio de Janeiro Campus Pinheiral, that allowed us to access and use some facilities during the expedition.

\section{References}

AOSA - Association Of Official Seed Analysts. Seed vigor testing handbook. East Lansing: AOSA, 1983. 93p. (Contribution, 32).

BESPALHOK FJC, GUERRA EP, OLIVEIRA R. Melhoramento de Plantas. Disponível em http://www.bespa. agrarias.ufpr.br/paginas/livro/capitulo\%208.pdf . Acesso em 16 de Nov. de 2018. 
BINOTTI FFS, HAGA KI, CARDOSO ED, ALVES CZ, SÁ ME de, ORIVALDO ARF, O. Efeito do período de envelhecimento acelerado no teste de condutividade elétrica e na qualidade fisiológica de sementes de feijão. Acta Scientiarum Agronomy. v.2(30): 247-254, 2008.

BRASIL. Sistema Nacional de Sementes e Mudas. Lei no 10.711, de 05 de agosto de 2003. Disponível em: http:// www.planalto.gov.br/ccivil_03/leis/2003/L10.711.htm. Acesso em: 16 Nov. 2018.

CHANG SM, SUNG JM. Deteriorative changes in primed sweet corn seeds during storage. Seed Science Technology, v.26, p.613-626, 1998.

COSTA NETO PLO. Estatística. São Paulo: Edgard Blücher, 1977. 264p.

DARIO FR. A importância da fauna na dinâmica da floresta. 2004. Disponível em: http://port.pravda.ru/brasil. Acesso em: 16/05/2005.

DIAS DCFS, MARCOS FILHO J. Electrical conductivity test for vigor evaluation in soybean seeds. Seed Research, v. 24, p. 1-10, 1996.

FAO - Food and Agriculture Organization of The United Nations. The State of the World's Land and Water Resources for Food and Agriculture (SOLAW), 2011. Disponível em: http://www.fao.org/news/story/en/ item/95153/icode/. Acesso: 16 Nov. 2018.

FLAVIO JJP, PAULA RC. Testes de envelhecimento acelerado e de condutividade elétrica em sementes de Dictyolomavandellianum A. Juss. Scientia Forestales, v.38, n.87, p.391-399, 2010.

FRANCO HA. Introdução à Fruticultura. 1. ed. Curitiba: Livro Técnico, 180p. 2016. ISBN: 978-85-8409-071-6.

GASPAR CM, NAKAGAWA J. Teste de condutividade elétrica em função do número de sementes e da quantidade de água para sementes de milheto. Journal of Seed Science, v. 24, n. 2, p. 70-76, 2002.

GUOLLO K, POSSENTI JC, FELIPPI M, DEL QUIQUI EM, DEBASTIANI AB. Avaliação da Qualidade Fisiológica de Sementes Florestais através do Teste de Condutividade Elétrica. Sci. Agrar. Parana., Marechal Cândido Rondon, v. 16, n. 3, jul./set., p. 374-382, 2017.

HAMPTON JG, TEKRONY DM. Handbook of vigour test methods. 3 ed. Zürich: ISTA, 1995. 117p.

LORENZI, HARRI. Árvores brasileiras: manual de identificação e cultivo de plantas arbóreas do Brasil, vol. 1/Harri Lorenzi. Nova Odessa, SP: Instituto Plantarum, 2016.

KRZYZANOWSKI FC, VIEIRA RD, FRANCA NETO J de B. Vigor de sementes: conceitos e testes. Londrina: ABRATES, 1999. 218p.

MARCHI JL, CICERO S M. Procedimentos para a condução do teste de condutividade elétrica em sementes. Informativo Abrates, v. 12, n. 1, p. 20-27, 2002.

MARCOS FILHO, J. Fisiologia de sementes de plantas cultivadas. Londrina: ABRATES, 2015. 659p

MILLER JC, MILLER JN. Statistics for analytical chemistry. 3. ed. Chichester: Ellis Horwood, 1993. 233p.

OLIVEIRA S. Tecnologia de sementes florestais: espécies nativas. Curitiba: UFPR; 2012.

PASSOS MAA, SILVA FJBC, SILVA ECA, PESSOA RC, SANTOS RC. Luz, substrato e temperatura na germinação de sementes de cedro-vermelho. Pesquisa Agropecuária Brasileira, v. 43, n. 2, p. 281-284, 2008.

REIS A. Fundação o Boticário de Proteção a Natureza. Natureza et Conservação. Curitiba-PR. v.1. nº1, 2003. 
SANTOS SRG, PAULA RC. Teste de condutividade elétrica para avaliação da qualidade fisiológica de sementes de Sebastiania commersoniana (BAIL) SMITH \& DOWNS - Euphorbiaceae. Journal of Seed Science, v. 27, n. 2, p. 136-145, 2005.

STEERE WC, LEVENGOOD WC, BONDIE JM. An electrical analyser for evaluating seed germination and vigour. Seed Science and Technology, v. 9, n. 2, p. 567-576, 1981.

VIEIRA R, KRZYZANOWSKI FC. Teste de condutividade elétrica. In: KRZYZANOWSKI, F. C. et al. Vigor de sementes: conceitos e testes. Londrina: ABRATES, 1999. p. 4.1-4.26. 